\title{
Identification and analysis of a gene (abpA) encoding a major amylase-binding protein in Streptococcus gordonii
}

\author{
Jeffrey D. Rogers, ${ }^{1}$ Elaine M. Haase, ${ }^{1}$ Alan E. Brown, ${ }^{1}$ \\ Charles W. I. Douglas, ${ }^{2}$ Justin P. Gwynn ${ }^{2}$ and Frank A. Scannapieco'
}

Author for correspondence: Frank A. Scannapieco. Tel: +1 716829 2013. Fax: +1 7168293942. e-mail: Frank_Scannapieco@sdm.buffalo.edu

1 Department of Oral Biology, School of Dental Medicine, State University of New York at Buffalo, Buffalo, NY 14214, USA

2 Department of Oral Pathology, University of Sheffield, Sheffield S10 2TA, UK
Oral streptococci such as Streptococcus gordonii bind the abundant salivary enzyme $\alpha$-amylase. This interaction may be important in dental plaque formation and metabolism, thus contributing to the initiation and progression of dental caries and periodontal disease, the two most common plaquemediated diseases. The conjugative transposon Tn916 was used to insertionally inactivate gene(s) essential to the expression of amylase-binding components of S. gordonii Challis, and a mutant deficient in amylase-binding (Challis Tn1) was identified. While wild-type strains of S. gordonii released both $20 \mathrm{kDa}$ and 82 kDa amylase-binding proteins into culture supernatants, Challis Tn1 expressed the $82 \mathrm{kDa}$ but not the $20 \mathrm{kDa}$ protein. The $20 \mathrm{kDa}$ amylase-binding protein was isolated from culture supernatants of $\mathbf{S}$. gordonif Challis by hydroxyapatite chromatography. A partially purified, functionally active $20 \mathrm{kDa}$ protein was sequenced from blots, and the $\mathrm{N}$-terminal sequence obtained was found to be DEP(A)TDAAT(R)NND. A novel strategy, based on the single-specific-primer polymerase chain reaction technique, enabled the gene inactivated by Tn916 to be cloned. Analysis of the resultant nucleotide sequence revealed an open reading frame of $585 \mathrm{bp}$, designated amylasebinding protein A (abpA), encoding a protein of $20 \mathrm{kDa}$ (AbpA), immediately downstream from the insertion site of Tn916. This protein possessed a potential signal peptide followed by a region having identity with the $\mathrm{N}$ terminal sequence of the $20 \mathrm{kDa}$ amylase-binding protein. These results demonstrate the role of the $20 \mathrm{kDa}$ protein in the binding of amylase to $S$. gordonii. Knowledge of the nature of amylase-binding proteins may provide a better understanding of the role of these proteins in the colonization of $S$. gordonii in the oral cavity.

Keywords: biofilms, dental plaque, salivary proteins, microbial adhesion/adherence, amylase-binding protein

\section{INTRODUCTION}

Several mammalian enzymes are known to specifically bind to bacteria. For example, plasmin (Lottenberg et al., 1992), lysozyme (Tellefson \& Germaine, 1986; Cimasoni et al., 1987; Roger et al., 1994) and lactoperoxidase (Roger et al., 1994) all bind to streptococci to

Abbreviations: BHI, brain heart infusion broth; HPS, human parotid saliva; TBST, Tris-buffered saline with Tween 20.

The GenBank accession number for the sequence reported in this paper is AF035817. influence their adhesion to and colonization of host surfaces. $\alpha$-Amylase, the most abundant enzyme in human saliva (Aguirre et al., 1987), also binds with high affinity to a number of the streptococci that are early colonizers of the tooth, including Streptococcus gordonii, S. mitis, S. parasanguis, S. crista and S. salivarius (Douglas, 1983; Scannapieco et al., 1989, 1994; Douglas et al., 1990; Kilian \& Nyvad, 1990; Handley et al., 1991; Gwynn \& Douglas, 1994). Amylase-binding bacteria constitute a substantial proportion of the total cultivable flora from human teeth (Tseng et al., 1992; Scannapieco et al., 1994), and amylase-binding bacteria appear to 
colonize only the mouths of animals having salivary amylase activity (Scannapieco et al., 1994). Amylase may also serve as an adherence receptor for amylasebinding bacteria (Scannapieco et al., 1995). Thus, amylase, together with other salivary components, may play an important role in the formation of dental plaque (Douglas, 1994; Scannapieco, 1994).

Amylase binds to $S$. gordonii through high-affinity receptors that appear to cluster around cell-division sites on the surface of actively dividing cells (Scannapieco $e t$ al., 1992). Bacterial cells in the exponential phase of growth are capable of binding more amylase than those in stationary phase (Scannapieco et al., 1992). The interaction of amylase with the surface of $S$. gordonii has been shown to be sensitive to treatment with proteases and periodate, suggesting that the amylase receptor is a protein or a glycoprotein (Douglas, 1990; Scannapieco et al., 1992). Further work suggested that amylase-binding components of 20 and $82 \mathrm{kDa}$ are associated with the cell surface and released into the culture supernatants of $S$. gordonii strains (Douglas, 1990; Gwynn \& Douglas, 1994). Furthermore, an alkalisoluble $20 \mathrm{kDa}$ component was extracted from $S$. gordonii G9B and interacted with immobilized amylase (Scannapieco et al., 1992). Taken together, these findings suggest that amylase binding to $S$. gordonii may be mediated by a multi-component, cell-surface-associated protein receptor that is subsequently released into the culture supernatant as the cell matures.

Transposon-mediated insertional gene inactivation has proven to be a powerful tool for the inactivation and cloning of bacterial genes (Clewell, 1981; GawronBurke \& Clewell, 1984; Harris et al., 1992). Transposon mutagenesis is particularly useful in identifying genes and gene products important to the expression of specific phenotypes for which screening assays are available. $S$. gordonii Challis, an amylase-binding strain, is particularly amenable to such an approach since it exhibits natural competence (LeBlanc \& Hassell, 1976) and therefore provides a convenient host for gene transfer.

The present study was performed to attempt to definitively identify and sequence amylase-binding component(s) of $S$. gordonii and to further explore the relationship between the 82 and $20 \mathrm{kDa}$ amylase-binding components. The $20 \mathrm{kDa}$ amylase-binding protein was isolated and its $\mathrm{N}$-terminal sequence determined. Further, a mutant of $S$. gordonii Challis deficient in amylase-binding was constructed following insertional gene inactivation using the conjugative transposon Tn916. The disrupted gene was then cloned employing a strategy based on the single-specific-primer polymerase chain reaction technique (Shyamala \& Ames, 1989; Novak et al., 1997). Analysis of the disrupted nucleotide sequences revealed an open reading frame consistent with a gene encoding the putative $20 \mathrm{kDa}$ amylasebinding protein.

\section{METHODS}

Bacterial strains, plasmids and culture conditions. S. gordonii strains Challis (NCTC 7868) and G9B, S. gordonii Challis Tn1 (this study), S. sanguis 10556, Escherichia coli strains DH1 (host for pAM620), JM109 and INVF' $\alpha$ (Invitrogen), and plasmids pAM620 (Yamamoto et al., 1987), pCR2.1 (Invitrogen), pVA856 (Macrina et al., 1983) and pCR2KB-7 (this study) were studied. The streptococcal strains were inoculated from frozen stocks on tryptic soy blood agar plates supplemented with $0.5 \%(\mathrm{w} / \mathrm{v})$ yeast extract (TSBY agar; Difco) or TSBY agar supplemented with tetracycline $\left(10 \mu \mathrm{g} \mathrm{ml}^{-1}\right)$ (TSBY-T; Sigma). Streptococcal strains were routinely cultured in either defined medium (Terleckyj et al., 1975), in TSBY broth or in brain heart infusion broth (BHI; Difco). The mutant strain was cultured in media supplemented with or without $10 \mu \mathrm{g}$ tetracycline $\mathrm{ml}^{-1}$. Cultures were typically incubated for $16-18 \mathrm{~h}$ at $37^{\circ} \mathrm{C}$ in a candle jar. E. coli strains were grown under aerobic conditions with shaking for 12-16 h at $37^{\circ} \mathrm{C}$ in Luria-Bertani broth (LB) and maintained on LB agar. Strains containing recombinant clones were plated on

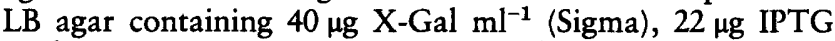
$\mathrm{ml}^{-1}$ (Sigma), and $100 \mu \mathrm{g}$ ampicillin $\mathrm{ml}^{-1}$ (Sigma).

Collection of saliva and purification of amylase. Human parotid saliva (HPS) was collected into chilled tubes from healthy donors using a modified Carlsen-Crittenden apparatus (Curby, 1953) following stimulation with $2 \%$ citric acid. The HPS was dialysed against distilled water and lyophilized. Salivary amylase was purified from lyophilized HPS as previously described (Scannapieco et al., 1989). For some experiments, whole saliva was collected by expectoration into a chilled tube, clarified by centrifugation, and used as a source of amylase.

Bacterial growth studies. $S$. gordonii Challis was grown in continuous culture at a range of dilution rates in a $\mathrm{LH} 210$ series chemostat (LH Engineering) having a pot volume of 11 at $37^{\circ} \mathrm{C}$ at $\mathrm{pH} 7.0$ in defined medium supplemented with arginine $\left(100 \mu \mathrm{g} \mathrm{ml}^{-1}\right)$, so that the cells were carbon limited. The $\mathrm{OD}_{600}$ and purity of the cultures were checked every $24 \mathrm{~h}$, and ten generation times at a given dilution rate were allowed to elapse to reach steady state. Cells were grown at dilution rates of between 0.264 and $0.048 \mathrm{ml}^{-1} \mathrm{~h}^{-1} \mathrm{I}^{-1}$, which corresponded to mean generation times of between 2.6 and $14.5 \mathrm{~h}$. Samples from each steady-state culture were collected, the cells were washed in $50 \mathrm{mM}$ phosphate buffer, $\mathrm{pH} 7 \cdot 0$, and resuspended in the same buffer to $\mathrm{OD}_{600} 1.0$ (approx. $4.2 \times 10^{8}$ cells $\left.\mathrm{ml}^{-1}\right)$. Aliquots of $1 \mathrm{ml}$ cell suspension were then centrifuged and the cell pellet resuspended in $1 \mathrm{ml}$ whole clarified saliva for $1 \mathrm{~h}$ at $37^{\circ} \mathrm{C}$. After incubation, the suspensions were centrifuged and the supernatants retained. Both the cells and supernatants were assayed for amylase activity using a commercial coupled assay kit (Sigma) as previously described (Douglas et al., 1992). For comparison, batch grown cells in BHI were also assayed for their ability to bind amylase. The saliva used as the source of amylase was from the same batch and was maintained as aliquots at $-20^{\circ} \mathrm{C}$ in order to standardize the amount of enzyme present in each assay between chemostat samples.

For construction of growth curves, streptococcal strains were first cultured in $10 \mathrm{ml} \mathrm{BHI}$ at $37^{\circ} \mathrm{C}$ in a candle jar overnight. The cultures were diluted $1: 100$ in the appropriate broth and incubated in a candle jar at $37^{\circ} \mathrm{C}$ until growth reached midexponential phase $\left(\mathrm{OD}_{600} 0.6\right)$. Each of the cultures were again diluted $1: 100$ into multiple $10 \mathrm{ml}$ aliquots of the same medium and incubated at $37^{\circ} \mathrm{C}$ in a candle jar without shaking. Growth was assessed hourly for $12 \mathrm{~h}$ and at $18 \mathrm{~h}$ by 
measurement of the $\mathrm{OD}_{600}$ of each broth culture. The bacterial cells were then removed by centrifugation at $5000 \mathrm{~g}$ for $10 \mathrm{~min}$ and the supernatants stored at $-20^{\circ} \mathrm{C}$. Proteins in the culture supernatants were precipitated by the addition of an equal volume of saturated ammonium sulfate, $\mathrm{pH} 7 \cdot 2$, and left overnight at $4{ }^{\circ} \mathrm{C}$. Precipitated material was collected by centrifugation at $5000 \mathrm{~g}$ for $30 \mathrm{~min}$, reconstituted in $10 \mathrm{mM}$ PBS, $\mathrm{pH} 7 \cdot 0$, exhaustively dialysed against distilled water and lyophilized.

SDSPAGE and Western blotting. To optimally separate lower-molecular-mass proteins $(<15 \mathrm{kDa})$, SDS-PAGE was performed as described by Giulian et al. (1983). Alternatively, proteins of molecular mass $>15 \mathrm{kDa}$ were separated by SDSPAGE (Laemmli, 1970). Apparent molecular masses were determined by comparison of the relative migration of bands of interest with known standard proteins. Gels were stained with $0.025 \%$ Coomassie brilliant blue R-250 (Bio-Rad) or with silver, using dichromate (Merril et al., 1982).

Western blotting (Burnette, 1981) was performed by electrotransfer of gels to Immobilon-P membranes (Millipore) for $45 \mathrm{~min}$ at $100 \mathrm{~mA}$ using a TE-70 SemiPhor semi-dry transfer unit (Hoefer). Membranes were blocked with $3 \%(w / v)$ nonfat dry milk in Tris-buffered saline, $\mathrm{pH} 8.0,0.05 \%(\mathrm{v} / \mathrm{v}\rangle$ Tween-20 (TBST), washed with TBST and incubated with primary rabbit antibody diluted in $1 \%(\mathrm{w} / \mathrm{v})$ nonfat dry milk in TBST. Primary antibodies utilized included rabbit polyclonal antisera to whole cells of S. gordonii (anti-G9B), to the purified $20 \mathrm{kDa}$ amylase-binding protein (anti-20 kDa) (Scannapieco et al., 1992) and to purified amylase (Scannapieco et al., 1989). The membranes were subsequently incubated with goat anti-rabbit IgG conjugated to alkaline phosphatase (Promega) diluted in $1 \%(w / v)$ nonfat dry milk in TBST and developed with the ProtoBlot Western Blot AP system (Promega).

Amylase-binding assays. Soluble ${ }^{125}$ I-labelled amylase binding to whole bacterial cells was investigated as previously described (Scannapieco et al., 1989). The binding of amylase by streptococcal components was assessed using a solid-phase amylase ligand-binding assay as previously described (Douglas, 1990; Gwynn \& Douglas, 1994). Briefly, streptococcal extracts or purified molecules in PBS were dotted on nitrocellulose (MSI). Alternatively, components were separated by SDS-PAGE and electrotransferred to Immobilon-P membranes or nitrocellulose. Blots were incubated with lyophilized HPS ( $1 \mathrm{mg} \mathrm{ml}^{-1}$ in $3 \%, \mathrm{w} / \mathrm{v}$, nonfat dry milk in TBST) for $1 \mathrm{~h}$, washed and incubated with antibody to purified human salivary amylase in $1 \%(\mathrm{w} / \mathrm{v})$ nonfat dry milk in TBST for $30 \mathrm{~min}$. The blots were then washed, incubated with goat antirabbit IgG conjugated to alkaline phosphatase (Promega) or to horseradish-peroxidase-conjugated swine anti-rabbit IgG and developed with appropriate reagents.

Transformation of S. gordonii Challis and screening for amylase-binding deficient mutants. Plasmids were isolated as described by Birnboim \& Doly (1979). Prior to transformation, competence was induced in $S$. gordonii Challis as described by Behnke (1981). Transformants were selected by plating cells onto TSBY-T agar and incubating at room temperature for $4 \mathrm{~d}$ in an anaerobic chamber $\left(85 \% \mathrm{~N}_{2}, 10 \%\right.$ $\left.\mathrm{H}_{2}, 5 \% \mathrm{CO}_{2}\right)$.

Transformants deficient in amylase binding were screened for by using a replica-plating method (Tseng et al., 1992). Colonies (200-300 per plate) were transferred onto nitrocellulose membranes overlaid onto TSBY-T agar using a Replipad (Schleicher \& Schuell). The membranes were in- cubated at $37^{\circ} \mathrm{C}$ under anaerobic conditions for $48 \mathrm{~h}$, blocked in PBS with $0.1 \%(\mathrm{w} / \mathrm{v})$ lipid-free BSA for $30 \mathrm{~min}$ and incubated in $20 \mathrm{ml}$ PBS containing $10^{6}$ c.p.m. ${ }^{125}$ I-labelled amylase $(\sim 1 \mu \mathrm{g})$ for $30 \mathrm{~min}$ with gentle agitation. The membranes were then washed with PBS until the c.p.m. eluted approached background levels, air dried and subjected to autoradiography. The inability of selected clones to bind amylase was confirmed by the solution-phase assay described above. Mutant strains unable to bind amylase were compared to the wild-type strain by Gram staining, evaluation of colony morphology on blood and mitis salivarius agars, comparison of biochemical metabolic profiles using the API Rapid Strep kit (bioMérieux Vitek) and by demonstrating that the mutant retained natural competence after transformation with a plasmid (pVA856) bearing an alternate antibiotic marker (erythromycin).

Determination of insertion number and genetic linkage studies. Streptococcal genomic DNA was isolated from the mutant (Challis Tn1) and wild-type strains as described by Coykendall \& Gustafson (1985) with the following modification. The bacteria were first incubated for $1 \mathrm{~h}$ at $37^{\circ} \mathrm{C}$ with $150 \mu \mathrm{g}$ each of lysozyme and mutanolysin $\mathrm{ml}^{-1}$ (Sigma). The number of $\mathrm{Tn} 916$ insertions present in the transformants was determined by treatment of genomic DNA isolated from the mutant strain with HindIII (Gibco-BRL). The restricted DNA was electrophoresed in $1.0 \%(\mathrm{w} / \mathrm{v})$ agarose gels and Southern blots were prepared by capillary transfer of DNA from gels to Hybond-N membranes (Amersham). Nucleic acid was crosslinked to the membranes by UV light fixation. Hybridization was performed according to the Photogene nucleic acid detection system version 2.0 (Gibco-BRL) protocol and the blots were probed with EcoRI-digested pAM620 biotinylated using the BioPrime system (Gibco-BRL). Southern blots were visualized using the Photogene nucleic acid detection system version 2.0 (Gibco-BRL).

Isolation and sequencing of the $20 \mathrm{kDa}$ amylase-binding component from $\mathrm{S}$. gordonii supernatants. Supernatant from BHI cultures of $S$. gordonii was dialysed against $10 \mathrm{mM}$ potassium phosphate buffer, $\mathrm{pH} 7 \cdot 0$, and then loaded onto an HTP hydroxyapatite cartridge $\left(5 \mathrm{ml}\right.$; Bio-Rad) at $4^{\circ} \mathrm{C}$. Bound proteins were eluted over a gradient of 10 to $400 \mathrm{mM}$ potassium phosphate, $\mathrm{pH} 7.0$, at a flow rate of $0.5 \mathrm{ml} \mathrm{min}^{-1}$, collecting $2 \mathrm{ml}$ fractions. Samples of these fractions were monitored by measuring $A_{280}$ and analysed by dotting $(2.5 \mu \mathrm{l})$ onto nitrocellulose. The membrane was then blocked with $5 \%(\mathrm{w} / \mathrm{v})$ haemoglobin, incubated in salivary amylase followed by horseradish-peroxidase-conjugated swine anti-rabbit $\mathrm{IgG}$ and visualized using appropriate developing reagents. Positive fractions were pooled and dialysed against $10 \mathrm{mM}$ phosphate buffer, $\mathrm{pH} 7 \cdot 0$, and lyophilized. Proteins were analysed by SDS-PAGE and the amylase ligand-binding assay.

Samples of the purified amylase-binding protein were run on $15 \%$ SDS-PAGE gels. Gels were equilibrated with several changes of $10 \mathrm{mM}$ CAPS, $\mathrm{pH} 11.0$, containing $10 \%(\mathrm{v} / \mathrm{v}\rangle$ methanol $\mathrm{pH} 11 \cdot 0$, then blotted onto a ProBlott (Applied Biosystems) membrane that had been pre-soaked in methanol. Blotting was carried out at $50 \mathrm{~V}$ for $30 \mathrm{~min}$ in equilibrating buffer. Protein bands were visualized by staining with $0.1 \%$ $(\mathrm{w} / \mathrm{v})$ Coomassie brilliant blue R-250. The protein band was then cut out of the blot and sequenced in an Applied Biosystems model $476 \mathrm{~A}$ sequenator by the Edman degradation reaction. The phenylthiohydantonin amino acid derivatives liberated by the degradation reaction were detected and analysed by measuring $A_{254}$.

Trypsin digestion of cell pellets and supernatants. Trypsin 
(DPCC treated, type XI; Sigma), was coupled to CNBractivated Sepharose 4B (Pharmacia Biotech) and titrated for activity against bovine serum albumin (fraction V; Sigma) to determine the minimum concentration of enzyme necessary for digestion. Bacterial cells were centrifuged, and supernatants were removed and stored at $-20^{\circ} \mathrm{C}$. Cell pellets were suspended in PBS, adjusted to $\mathrm{OD}_{600} 10$, and $10 \mu \mathrm{l}$ trypsincoupled beads was added to $1 \mathrm{ml}$ of the standardized cell suspension and mixed end-over-end at $37^{\circ} \mathrm{C}$ for $30 \mathrm{~min}$. Supernatants were dialysed for $3 \mathrm{~d}$ against distilled water and lyophilized. Culture supernatants $(100 \mu \mathrm{l})$, first adjusted to pH 8.0 with $0.1 \mathrm{M}$ Tris, $\mathrm{pH} 9.5$, were mixed with $2 \mu$ trypsincoupled beads and incubated for $5,10,30$ and $60 \mathrm{~min}$ at $37^{\circ} \mathrm{C}$. Hydrolysis was stopped by centrifuging the suspension for $2 \mathrm{~min}$ at $12000 \mathrm{~g}$ and boiling the supernatants for $2 \mathrm{~min}$. Controls for each experiment included the cell pellet or supernatant without trypsin incubated at $37^{\circ} \mathrm{C}$ for $0 \mathrm{~h}$ and $1 \mathrm{~h}$ and trypsin in $0.1 \mathrm{M}$ Tris $/ \mathrm{HCl}, \mathrm{pH} 8.0$, incubated alone at $37^{\circ} \mathrm{C}$ for $0 \mathrm{~h}$ and $1 \mathrm{~h}$. Samples were dissolved or diluted in the appropriate sample buffer, separated by SDS-PAGE, electroblotted and examined by the amylase ligand-binding assay or immunostaining with the anti- $20 \mathrm{kDa}$ antibody.

PCR cloning of the disrupted amylase-binding-protein gene. HindIII/KpnI-restricted Challis Tn1 genomic DNA was shotgun-cloned into pBluescript II SK+ (Stratagene) and ligated with T4 DNA polymerase (Gibco-BRL) at $14^{\circ} \mathrm{C}$ overnight. PCR primers based on the published sequences of both the vector (5'-GGTGCCATAGGTGTGAATCA-3'; SK primer) and Tn916 (5'-AGAGAAGCAACAGGAGCGTC-3'; Tn916L) were used to amplify the ligation reaction for the rapid identification of the disrupted nucleic acid sequence. After initial denaturation for $3 \mathrm{~min}$ at $94^{\circ} \mathrm{C}, 30$ cycles were performed as follows: $1 \mathrm{~min}$ at $94^{\circ} \mathrm{C}, 2 \mathrm{~min}$ at $55^{\circ} \mathrm{C}$ and $3 \mathrm{~min}$ at $72^{\circ} \mathrm{C}$. This was followed by $10 \mathrm{~min}$ at $72^{\circ} \mathrm{C}$ for completion of the extension reaction. Partial sequencing of the PCR product was performed by the Nucleic Acid Sequencing Facility at the State University of New York at Buffalo. To eliminate vector sequences, a new primer was synthesized and designated PCRF (5'-ATCCGTTTGGTCCCATAGGT-3') which was used to generate a PCR product from Challis Tn1 DNA using the identical thermocycler program described above. The resulting PCR product contained a portion of Tn916 and streptococcal DNA. This product was subcloned into pCR2.1 (Invitrogen) and the newly constructed plasmid designated pCR2KB-7.

Analysis of the cloned streptococcal DNA fragment. To confirm the insertion of the PCR-amplified fragment into pCR2KB-7, PCR was performed using pCR2KB-7 as the template DNA and PCRF and Tn916L as the reaction primers. Challis Tn1 genomic DNA served as the positive control and pCR2.1 as the negative control. The reaction conditions were identical to those described above. The PCR product from Challis Tn1 was subsequently biotinylated and used to probe Southern blots containing Challis and Challis Tn1 genomic DNA, the PCR amplification product that was subcloned into pCR2.1 and the vector (pCR2.1) alone. Southern blotting conditions were as described above.

Nucleotide sequencing and analysis. Single-stranded DNA was prepared using the M13K07 helper phage (Promega) according to the method of Yanisch-Perron et al. (1985). Sequencing was performed by the dideoxynucleotide chaintermination method (Sanger et al., 1977) using Sequenase version 2.0 DNA polymerase, $\left[{ }^{35} \mathrm{~S}\right] \mathrm{dATP} \alpha \mathrm{S}$ and Sequenase kit reagents (United States Biochemical). Sequence data, which were confirmed by the Nucleic Acid Sequencing Facility at the
State University of New York at Buffalo, were analysed with HIBIO DNASIS (Hitachi Software Engineering) and Statistical Analysis of Protein Sequences (SAPS) (Brendel et al., 1992) software. Nucleotide and deduced amino acid sequences were compared with previously published genes using BLAST (Altschul et al., 1990) and PROsITE (Bairoch et al., 1996) software.

\section{RESULTS}

\section{Generation of a mutant of S. gordonii Challis deficient in amylase-binding}

The naturally competent $S$. gordonii strain Challis (LeBlanc \& Hassell, 1976) was mutagenized with the conjugative transposon $\operatorname{Tn} 916$. A transformation rate of approximately $10^{-4}$ was observed and 6000 colonies were initially screened for the non-amylase-binding phenotype using a replica-plating method (Tseng et al., 1992). The initial screening identified 30 colonies that appeared to be amylase-binding deficient $\left(\mathrm{AB}^{-}\right)$, which were subcultured and rescreened using the liquid-phase ${ }^{125}$ I-labelled amylase binding assay. This screening yielded a single $\mathrm{AB}^{-}$mutant strain (Challis Tn1). The binding of amylase to Challis $\mathrm{Tn} 1$ was found to be significantly less than that of the wild-type and nearly identical to that observed with $S$. sanguis 10556 , a strain known not to bind amylase (Fig. 1). The colony morphology of Challis Tn1 and the wild-type was indistinguishable on both blood and mitis salivarius agar. In addition, no metabolic differences were noted when the mutant and wild-type strains were compared using the API Rapid Strep system, and the competence of Challis Tn1 was not affected as demonstrated by successful transformation with pVA856.

The stability of Challis $\operatorname{Tn} 1$ in the absence of tetracycline was assessed. The proportion of tetracycline-resistant colonies observed in cultures in the absence of tetracycline diminished with each subsequent passage so that after five passages only $50 \%$ of the total c.f.u. were tetracycline resistant.

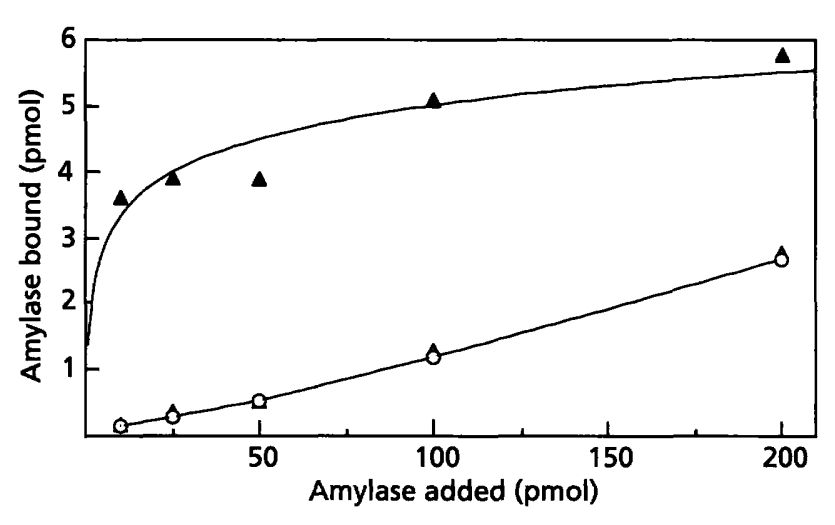

Fig. 1. Binding of ${ }^{125}$-labelled amylase to $S$. gordonii Challis $(\mathbf{A})$, Challis $\operatorname{Tn} 1(\triangle)$ and S. sanguis $10556(O)$. Data points represent the mean value of duplicate samples. 
Table 1. Relationship between growth rate and amylase-binding ability in S. gordonii

The values are the means of duplicate determinations, which were within $10 \%$ of each other.

\begin{tabular}{|ccc|}
\hline $\begin{array}{l}\text { Generation } \\
\text { time } \\
(\mathbf{h})\end{array}$ & $\begin{array}{c}\text { Amount of } \\
\text { amylase bound } \\
\left(\mathrm{U} \mathrm{m} \mathrm{m}^{-1}\right)\end{array}$ & $\begin{array}{c}\text { Percentage of amylase } \\
\text { activity removed } \\
\text { from saliva }\end{array}$ \\
\hline $2 \cdot 6$ & $38 \cdot 6$ & $32 \cdot 1$ \\
$4 \cdot 6$ & $22 \cdot 2$ & $28 \cdot 0$ \\
$6 \cdot 4$ & $20 \cdot 6$ & $25 \cdot 2$ \\
$14 \cdot 5$ & $18 \cdot 2$ & $20 \cdot 0$ \\
\hline
\end{tabular}

\section{Determination of Tn916 insertion number and genetic linkage studies}

Southern blots of HindIII digests of wild-type and Challis Tn1 genomic DNA were probed with the biotinylated pAM620, which contains Tn916. Since Tn916 has a single HindIII restriction site, digestion with this enzyme would yield two fragments per insert following digestion with HindIII. Only a single insertion of $\operatorname{Tn} 916$ was noted in Challis $\operatorname{Tn} 1$ as demonstrated by the presence of only two hybridization bands following digestion with HindIII. The $15 \mathrm{~kb}$ and $8.2 \mathrm{~kb}$ bands associated with the Challis Tn1 genomic DNA were absent in the wild-type genomic DNA, and the pAM620 probe did not hybridize with $S$. gordonii wild-type DNA, suggesting there were no significant homologies between the plasmid vector, transposon and wild-type chromosomal DNA.

Linkage of the Tn916 insertion with the loss of amylase binding was evaluated by transformation of wild-type $S$. gordonii Challis with Challis Tn1 genomic DNA. Following selection on tetracycline-containing plates, 25 transformants were randomly selected and evaluated for amylase binding. None of these secondary transformants bound amylase at levels greater than that seen for $S$. sanguis 10556 , the negative control. In addition, the hybridization patterns observed for the original mutant and three randomly selected transformants were identical. Together, these data demonstrate the genetic linkage between the $\mathrm{AB}^{-}$phenotype and the insertion of Tn916 in Challis Tn1.

\section{Kinetics of the release of amylase-binding protein into culture supernatants}

To determine the effect of growth rate on amylasebinding ability, $S$. gordonii Challis was grown in continuous culture at four different growth rates (Table 1). As the mean generation time decreased (i.e. the faster the growth rate), the more amylase the bacteria were able to bind. At the fastest growth rate studied (mean generation time $2.6 \mathrm{~h}$; dilution rate $0.264 \mathrm{ml}^{-1} \mathrm{~h}^{-1} \mathrm{l}^{-1}$ ), the amount of amylase bound per $4.2 \times 10^{8}$ cells was more than double the level bound by cells grown at the slowest growth rate $\left(14.5 \mathrm{~h} ; 0.048 \mathrm{ml}^{-1} \mathrm{~h}^{-1} \mathrm{l}^{-1}\right)$. The mean amount of amylase bound by cells grown in BHI batch culture was $57 \mathrm{U} \mathrm{ml}^{-1}$, which was $47 \%$ more than the amount bound by cells grown at the fastest growth rate studied in the chemostat.

When the growth of wild-type $S$. gordonii Challis was compared to that of the $\mathrm{AB}^{-}$mutant Challis Tn1 in the absence of tetracycline, the growth curves were nearly identical at all time points, demonstrating that normal growth was not significantly disrupted by the insertion of $\operatorname{Tn} 916$ into the chromosome. When tetracycline was included in the growth medium of Challis Tn1, the lag phase of the mutant was prolonged by approximately $1 \mathrm{~h}$, although the duration of the exponential phase remained unchanged.

The appearance of amylase-binding proteins in the culture supernatant at various times during the growth cycle was also determined by the amylase ligand-binding assay. When standardized supernatant concentrates were analysed in the amylase ligand-binding assay (Fig. $2 \mathrm{a})$ both the $20 \mathrm{kDa}$ and $82 \mathrm{kDa}$ components were found to be present in stationary-phase culture supernatants of wild-type $S$. gordonii G9B and Challis. The $20 \mathrm{kDa}$ component was also detected at $1 \mathrm{~h}$ and continued to increase in concentration during the next $12 \mathrm{~h}$, reaching a plateau during the stationary phase. In control experiments, the $20 \mathrm{kDa}$ and $82 \mathrm{kDa}$ components were not detected when amylase was omitted from the blocking step of the amylase ligand-binding assay (Fig. 2b). Similar blots probed with the anti$20 \mathrm{kDa}$ antibody clearly demonstrated that the $20 \mathrm{kDa}$ component was produced by the wild-type strain, but was absent from the mutant strain (Fig. 2c).

The $20 \mathrm{kDa}$ component was not observed to be present on the cell surface or in the culture supernatant of the mutant strain Challis Tn1 at any time during the growth cycle. However, the mutant strain cultured with or without tetracycline always expressed the $82 \mathrm{kDa}$ component, which, like the wild-type strains, was not detected until the late-exponential phase of growth. When surface extracts and culture supernatants of Challis Tn1 were evaluated by silver-stained SDS-PAGE and immunoblotting using anti-G9B antibody, only the $20 \mathrm{kDa}$ component appeared to be absent from the mutant (Fig. 3) and no additional stained components were detected.

To further characterize the relationship between the $20 \mathrm{kDa}$ and $82 \mathrm{kDa}$ components, supernatant samples were prepared by incubation at $37^{\circ} \mathrm{C}$, at $100^{\circ} \mathrm{C}$ for $90 \mathrm{~s}$ with or without $\beta$-mercaptoethanol and at $100^{\circ} \mathrm{C}$ for $30 \mathrm{~min}$ in SDS-PAGE sample buffer. When gels were run under denaturing conditions the apparent molecular masses of both the $20 \mathrm{kDa}$ and the $82 \mathrm{kDa}$ components were not altered by any of the sample conditions employed, as determined by the amylase ligand-binding assay.

\section{Isolation of the amylase-binding components}

Hydroxyapatite chromatography was performed to isolate the $20 \mathrm{kDa}$ component from BHI-cultured cells 
(a)

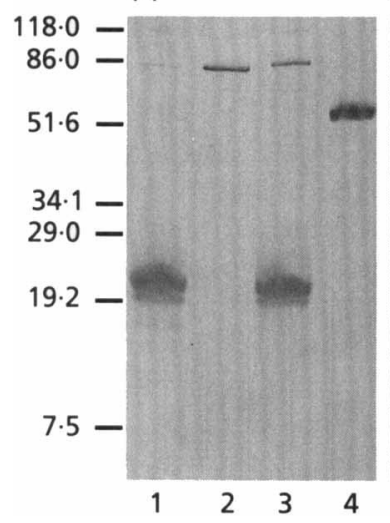

(b)

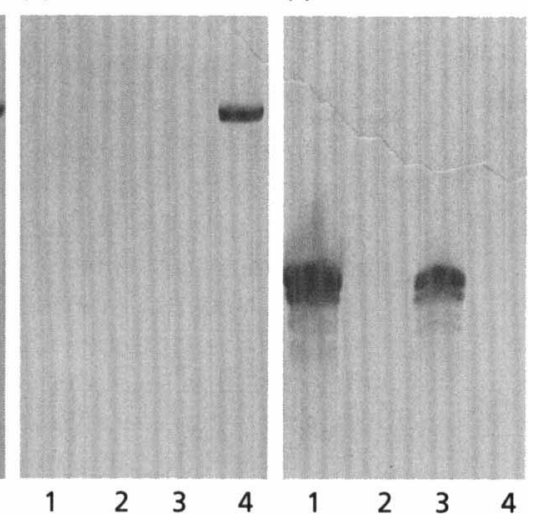

Fig. 2. Expression of amylase-binding proteins in stationary-phase supernatants applied to $20 \%$ Giulian gels in the amylase ligand-binding assay and Western blot. (a) Amylase ligand-binding assay (blot probed with amylase followed by anti-amylase antibody); (b) ligand-binding assay without amylase, probed with anti-amylase antibody; (c) blot probed with anti-20 kDa antibody. Lane1, $S$. gordonii Challis wildtype; lane 2, Challis Tn1; lane 3, S. gordonii G9B; lane 4, purified amylase $(1.5 \mu \mathrm{g})$. Molecular mass markers are indicated in kDa.

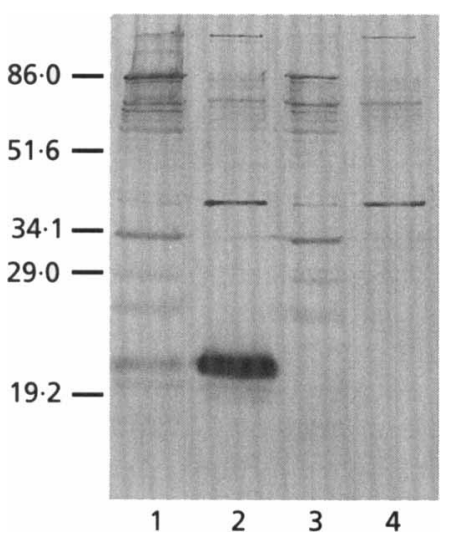

Fig. 3. Immunoblot ( $12.5 \%$ Laemmli gel) of stationary-phase cell pellets and supernatants from $S$. gordonii Challis wild-type strain and the $A B^{-}$mutant Challis $T n 1$ probed with antibody to S. gordonii G9B whole cells. Lane 1, S. gordonii Challis wildtype cell pellet; lane 2, wild-type supernatant; lane 3 , Challis Tn1 cell pellet; lane 4, Challis Tn1 supernatant. Molecular mass markers are indicated in $\mathrm{kDa}$.

of $S$. gordonii Challis. Fractions containing amylasebinding activity, as determined by the amylase ligandbinding assay, were eluted from the hydroxyapatite matrix with $300-400 \mathrm{mM}$ potassium phosphate buffer and had as their major constituent the $20 \mathrm{kDa}$ component. The $\mathrm{N}$-terminal sequence of the $20 \mathrm{kDa}$ amylasebinding protein was determined on directly blotted material and no other contaminating proteins in that region of the blot were noted. The amino acid sequence obtained was found to be DEPTDAATNND. The $\mathrm{P}$ at position 3 was equivocal and might be identified as $\mathrm{A}$, and the $T$ at position 8 was equivocal and might be identified as $\mathrm{R}$.

\section{Trypsin sensitivity of the $\mathbf{2 0 ~ k D a}$ amylase-binding component}

Cell pellets from $S$. gordonii G9B were digested with trypsin to provide further evidence of the protein nature of this component. A time-course study demonstrated that the $20 \mathrm{kDa}$ protein disappeared by 30 min with the concomitant appearance of $10 \mathrm{kDa}$ and $7 \cdot 7 \mathrm{kDa}$ fragments, which were reactive with the anti- $20 \mathrm{kDa}$ antibody (Fig. 4c). Similarly, the $20 \mathrm{kDa}$ protein obtained from culture supernatant was initially digested into $12 \mathrm{kDa}$ and $11 \mathrm{kDa}$ fragments, with increasing amounts of a $7.6 \mathrm{kDa}$ and other lower-molecular-mass fragments appearing as digestion progressed (Fig. 4b). Furthermore, when the trypsin-treated culture supernatants were tested in the amylase ligand-binding assay, the $20 \mathrm{kDa}$ immunoreactive fragment was not apparent after digestion (Fig. 4a). However, no functional fragments smaller than $18 \mathrm{kDa}$ were reliably detected by this assay. The same results were obtained when $S$. gordonii G9B was evaluated (data not shown).

\section{Cloning and sequencing of the gene encoding the amylase-binding protein}

Since previous attempts to clone the gene or genes encoding amylase-binding components proved problematical, a novel strategy was devised for cloning the disrupted gene from Challis Tn1 (Fig. 5). After ligation of the HindIII/Kpnl-restricted Challis Tn1 genomic DNA into pBluescript II SK + , the vector-specific primer (SK) and a primer for the left end of Tn916 (Tn916L) were used to amplify the ligation reaction. A $2 \mathrm{~kb}$ product was detected by electrophoresis and sequences from pBluescript II SK,$+ S$. gordonii and Tn916 were identified by partial DNA sequencing. PCR amplification of the vector alone failed to produce a $2 \mathrm{~kb}$ product.

To remove plasmid DNA from the PCR product, PCR of genomic Challis Tn1 DNA was performed using the original Tn916L primer as well as PCRF, a primer based on sequence data from the initial PCR product described above, which was nested downstream from the insertion site in pBluescript II SK + . A $2 \mathrm{~kb}$ product generated by PCR was biotinylated and used as a probe for Southern blotting. In addition to binding as expected with Challis Tn1 DNA, the probe also hybridized with wild-type Challis genomic DNA and with itself. Importantly, it failed to hybridize with pBluescript II SK + or pCR2.1, 
(a)

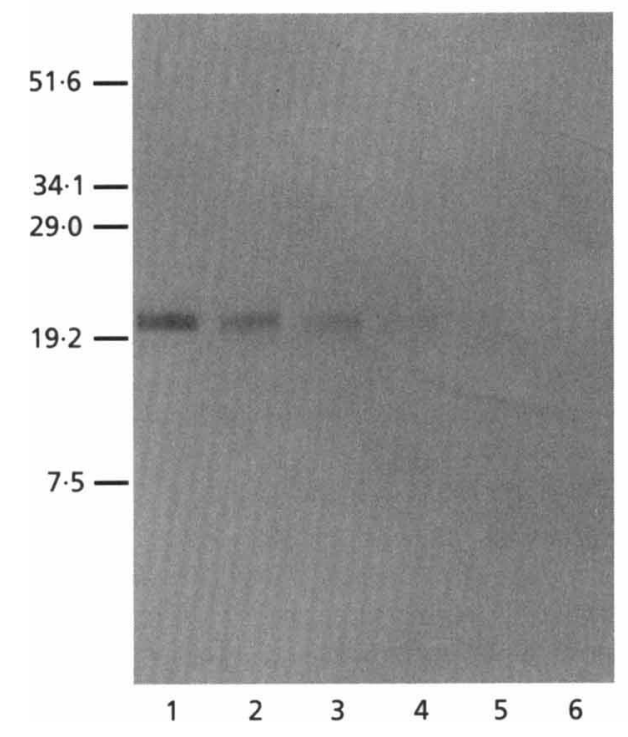

(b)

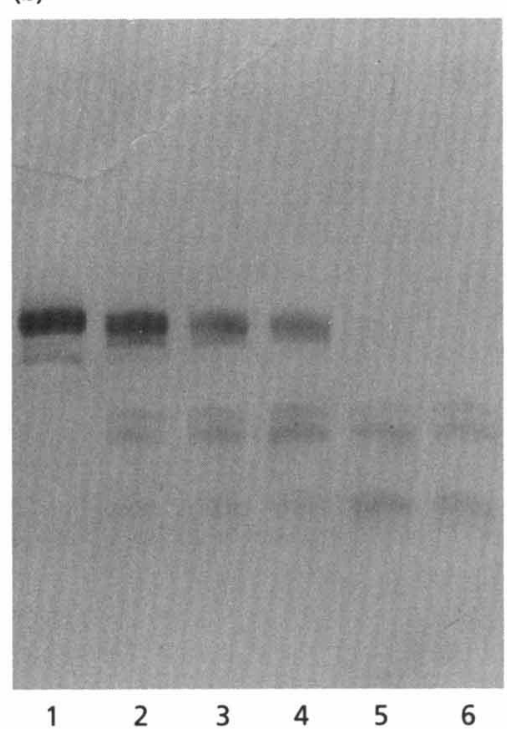

(c)

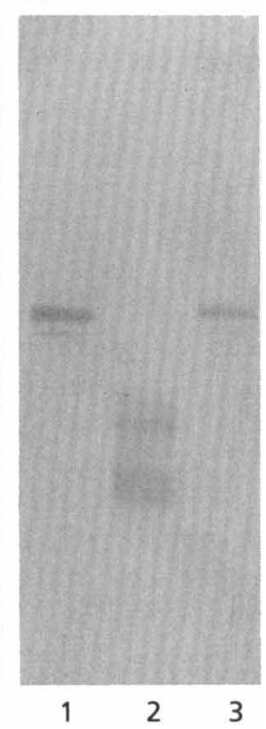

Fig. 4. Time course of trypsin digestion of the $20 \mathrm{kDa}$ protein from S. gordonii Challis. (a) Supernatant probed by amylase ligand-binding assay; (b) supernatant probed with anti-20 kDa antibody; (c) cell pellet probed with anti-20 kDa antibody. For (a) and (b): lane 1, $0 \mathrm{~h}$, no trypsin; lane 2, $0 \mathrm{~h}$, trypsin; lane 3, $5 \mathrm{~min}$, trypsin; lane 4, $10 \mathrm{~min}$, trypsin; lane 5, $30 \mathrm{~min}$, trypsin; lane 6, $1 \mathrm{~h}$, trypsin. For (c): lane 1, 0 h, no trypsin; lane 2, $30 \mathrm{~min}$, trypsin; lane 3, $30 \mathrm{~min}$, no trypsin. Molecular mass markers are indicated in $\mathrm{kDa}$.

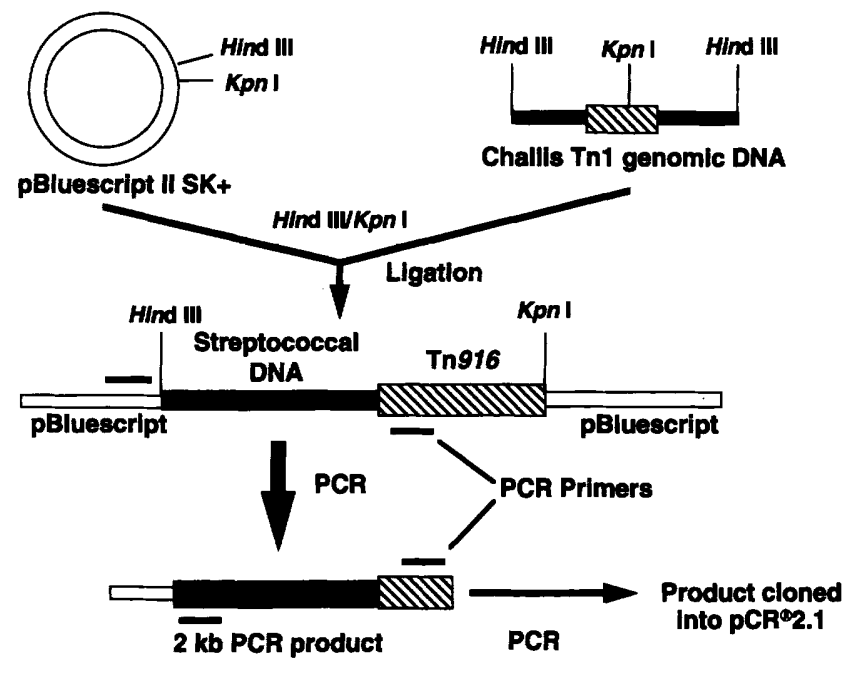

Fig. 5. Strategy for cloning the amylase-binding protein (abpA) gene of S. gordonii Challis.

the vector used for the subsequent subcloning of the PCR fragment, demonstrating that the plasmid vector sequences had been eliminated.

\section{Subcloning of the amplified streptococcal DNA}

The T/A cloning vector pCR2.1 was used for cloning the PCR product. The $2 \mathrm{~kb}$ PCR product (which represents the streptococcal sequence downstream from the Tn916 insertion site) was ligated into pCR2.1 and the new plasmid construct was designated pCR2KB-7. When this construct was incubated with $K p n \mathrm{I}$, a fragment of $5.9 \mathrm{~kb}$ was obtained, thus confirming the presence of a $2 \mathrm{~kb}$ insert within the construct. When this construct was subjected to PCR using the PCRF and Tn916L primers, a fragment of $2 \mathrm{~kb}$ was obtained, while a similar reaction using the $\mathrm{pCR} 2.1$ vector alone yielded no product. When Challis Tn1 genomic DNA was PCR amplified using the same primers, a product of $2 \mathrm{~kb}$ was also obtained. These data suggest that the streptococcal sequence downstream from the $\operatorname{Tn} 916$ insertion site was successfully cloned.

\section{Nucleotide sequencing and sequence analysis}

A total of 1013 bases of the cloned streptococcal $2 \mathrm{~kb}$ PCR product were sequenced in both directions. A sequence corresponding to the $3^{\prime}$ end of $\operatorname{Tn} 916$ was found at the $5^{\prime}$ end of the cloned fragment. A potential open reading frame of 585 bp encoding a protein of 195 amino acid residues was noted $15 \mathrm{bp}$ downstream from the junction of $\operatorname{Tn} 916$. This open reading frame encodes a protein with a predicted molecular mass of $20505 \mathrm{Da}$. This closely approximates the molecular mass of the $20 \mathrm{kDa}$ amylase-binding protein previously identified from S. gordonii Challis (Douglas, 1990; Scannapieco et al., 1992; Gwynn \& Douglas, 1994). This open reading frame was designated $a b p A$ (amylase-binding protein A). A potential Shine-Dalgarno sequence, AAGGAGA, was noted 7 bp upstream from the putative ATG start codon of $a b p A$. This gene was terminated by a TAA codon, with two stop codons noted in a stretch of 12 nucleotides and followed by seven thymidines. This 


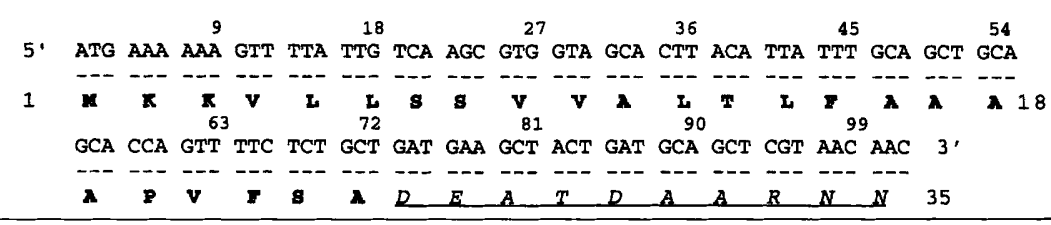

Fig. 6. Partial nucleic acid and deduced amino acid sequence of the abpA gene. Amino acids in bold letters indicate the deduced signal peptide; underlined italicized amino acid sequence denotes homology with $\mathrm{N}$-terminal amino acids of the purified $20 \mathrm{kDa}$ protein. motif is typical of previously reported E. coli and streptococcal transcription terminators (Suvorov et al., 1997). The overall $\mathrm{G}+\mathrm{C}$ content of $a b p A$ was $38 \mathrm{~mol} \%$, which is within the range noted for streptococcal genes $(34-46 \mathrm{~mol} \%)$. Based on this sequence, it is clear that Tn916 inserted immediately upstream of the $a b p A$ gene to inhibit the expression of the AbpA protein at the level of transcription.

Analysis of the deduced amino acid sequence revealed that the first 24 amino acids of the putative protein are consistent with a hydrophobic signal peptide characteristic of secreted proteins (Fig. 6). This signal peptide was followed by a region of 11 amino acids, representing the N-terminal region of the secreted protein, which shared identity (at least 9 and probably all 11 residues) with the N-terminal sequence data obtained for the $20 \mathrm{kDa}$ amylase-binding protein purified from S. gordonii Challis as described above.

No potential membrane-spanning or lipoprotein [L(S/A)(A/G)C(S/G) (Sutcliffe \& Russell, 1995)] consensus sequences were noted. However, a potential cellwall anchor hexapeptide motif compatible with those of other Gram-positive surface proteins may be present within the C-terminal region of AbpA [LPKTSA; residues 188-193 (Schneewind et al., 1995)]. Further analysis of the deduced amino acid sequence by BLAST searching revealed no significant homology with any known proteins produced by other bacteria.

As described above, partial digestion of AbpA with trypsin yielded fragments of $12,11,10$ and $7.7 \mathrm{kDa}$. Inspection of the predicted sequence of $\mathrm{AbpA}$ revealed potential tryptic fragments as follows. Digestion at residue 92 (lysine) would yield major fragments of $7 \cdot 7$ and $11 \mathrm{kDa}$. Digestion at residue 107 (arginine) would yield a fragment of 10 and $7 \cdot 7 \mathrm{kDa}$, while digestion at residue 75 (arginine) would yield a $12 \mathrm{kDa}$ fragment.

\section{DISCUSSION}

The results of the present study confirm the presence of $20 \mathrm{kDa}$ and $82 \mathrm{kDa}$ amylase-binding components on the surface of S. gordonii (Douglas, 1990; Scannapieco et al., 1992; Gwynn, 1995). These results also extend previous studies by establishing that the $20 \mathrm{kDa}$ component is essential for the binding of amylase to the cell surface. While both $S$. gordonii Challis and G9B produced amylase-binding components of similar apparent molecular mass $\left(20\right.$ and $82 \mathrm{kDa}$ ), the $\mathrm{AB}^{-}$mutant Challis Tn1 produced the $82 \mathrm{kDa}$ but not the $20 \mathrm{kDa}$ protein.
A number of observations suggest that the 20 and $82 \mathrm{kDa}$ components are structurally distinct. Present and previous studies revealed that while the $20 \mathrm{kDa}$ protein was released into the medium from the lag phase through the stationary phase of growth, the $82 \mathrm{kDa}$ protein was released only during the late-exponential and stationary phases (Gwynn \& Douglas, 1994). Growth of S. gordonii Challis in the presence of a variety of protease inhibitors such as EDTA, PMSF, SDS and trypsin inhibitor failed to prevent the appearance of the low-molecular-mass component (Gwynn \& Douglas, 1994). When applied to denaturing SDS-PAGE, neither the $20 \mathrm{kDa}$ nor the $82 \mathrm{kDa}$ component was heat modifiable and both proteins appeared to lack intermolecular disulfide linkages, suggesting that each component was monomeric. Subsequent nucleic acid sequence analysis of the cloned gene revealed no cysteine residues within this protein, thus supporting these observations. Furthermore, while the ability of the $82 \mathrm{kDa}$ protein to bind amylase in the amylase ligand-binding assay was abolished by periodate treatment, binding of the $20 \mathrm{kDa}$ protein was unaffected, suggesting the involvement of carbohydrate in the binding of amylase to the $82 \mathrm{kDa}$ component but not to the $20 \mathrm{kDa}$ component (Gwynn \& Douglas, 1994). Amylase binding to the $82 \mathrm{kDa}$ protein was prevented by the presence of the amylase substrate analogue acarbose, whereas the binding of amylase to the $20 \mathrm{kD}$ a protein was unaffected, suggesting different sites of attachment on the amylase molecule (Gwynn \& Douglas, 1994). Antibody raised to the $20 \mathrm{kDa}$ protein did not appreciably react with the $82 \mathrm{kDa}$ component. Finally and most notably, the $20 \mathrm{kDa}$ protein, while present in the wild-type strain, was found to be completely absent from an amylasebinding-deficient mutant of $S$. gordonii Challis. Indeed, the only detectable difference in protein profiles between stationary phase wild-type and mutant strains was the absence of the $20 \mathrm{kDa}$ protein from Challis Tn1. No significant difference was noted in the generation time between the wild-type and mutant strains once exponential phase was reached, indicating that lack of the $20 \mathrm{kDa}$ protein did not affect growth.

It has been suggested that the $20 \mathrm{kDa}$ component is a protein, mostly supported by the observation that amylase-binding to these bacteria is inhibited by treatment of the cells with proteases. The present trypsin digestion studies revealed that the $20 \mathrm{kDa}$ component is indeed degraded into components of $7 \cdot 6-12 \mathrm{kDa}$, providing further evidence for the protein nature of this component. The distribution of the amylase-binding components on the cell surface of $S$. gordonii is confined 
to the cell division septa on dividing cells or to polar zones on single cells (Scannapieco et al., 1992). As these regions of the cell are the proposed sites for formation of new cell wall material (Higgins \& Shockman, 1970), it has been suggested that the $20 \mathrm{kDa}$ protein is found only on nascent cell wall and is then released into the culture medium. Implicit in such a concept is that cells not in the process of dividing will probably be unable to bind amylase or will have a reduced binding capacity. This is supported by results of the present study which demonstrate that cells growing and dividing more rapidly in a chemostat bound more amylase than cells growing slowly in the same medium. It is presently not known if slow-growing cells express lower levels of AbpA on the cell surface, or if this protein is masked on these cells. The finding of a potential cell-wall-anchoring motif at the C-terminus of AbpA (Schneewind et al., 1995) is consistent with experimental evidence that amylasebinding to intact cells and cell walls can be abolished by trypsin. The presence of the molecule in culture supernatants may be due to physiological turnover and release of peptidoglycan fragments with linked proteins into the culture medium. However, the AbpA sequence differs from other anchors in that it lacks the $23 \mathrm{C}$-terminal hydrophobic amino acids thought to be typical of cellwall proteins.

The role of the $82 \mathrm{kDa}$ protein in amylase binding is presently unclear. This component may function as part of a heterotypic amylase receptor; the $20 \mathrm{kDa}$ protein may influence the conformation of the $82 \mathrm{kDa}$ protein. On the intact cell, the $82 \mathrm{kDa}$ protein may not present a functional conformation in the absence of the $20 \mathrm{kDa}$ protein. Thus, in this model, the $20 \mathrm{kDa}$ protein would be essential for amylase binding to intact cells. Determination of the function of the $82 \mathrm{kDa}$ protein awaits the construction of a mutant deficient in the $82 \mathrm{kDa}$ protein. Of course, the possibility also exists that the $82 \mathrm{kDa}$ protein fortuitously binds amylase in the in vitro ligand-binding studies but does not actually contribute to amylase binding to intact cells.

As the available evidence suggested that amylase binding to $S$. gordonii is probably mediated by a surface protein(s), initial attempts were made to clone the gene(s) for the amylase-binding protein(s) from this organism, but these were unsuccessful. For example, genomic libraries of $S$. gordonii Challis DNA prepared in the vectors $\lambda \mathrm{gt} 11$ and $\lambda \mathrm{GEM}-11$ were screened with antibody prepared against the amylase-binding $20 \mathrm{kDa}$ component isolated from SDS-PAGE gels (Scannapieco et al., 1992), as well as with radioiodinated amylase. Both libraries contained abundant recombinant clones expressing antigens cross-reactive with antibody prepared against whole cells of $S$. gordonii G9B. However, of over 100000 recombinants screened, no positive clones expressing antigen or functional receptor activity were obtained.

Alternative approaches were therefore sought to identify genes involved in amylase binding to these streptococci. Insertional gene inactivation using the conjugative transposon $\mathrm{Tn} 916$ resulted in the isolation of a single mutant exhibiting a non-amylase-binding phenotype. Only a single insertion of Tn916 was observed in transformants of $S$. gordonii Challis as opposed to the multiple inserts previously reported (Gawron-Burke \& Clewell, 1984). This is significant in that multiple transposon insertions would make analysis of the transformant much more difficult. Genetic linkage between the insertional event and the loss of amylasebinding activity established that the observed phenotype was probably not the result of a spontaneous mutation but was due to the insertion of $\operatorname{Tn} 916$ into the bacterial chromosome just upstream from the $a b p A$ gene. Since the inverted repeat regions of $\operatorname{Tn} 916$ direct its insertion into homologous regions of the bacterial chromosome that are A/T rich, Tn916 appears to have inserted into such regions upstream from $a b p A$. The relatively large size of Tn916 and the lack of known promoters at its 3' end that could mediate transcription of $a b p A$ by readthrough would thus prevent transcription of $a b p A$ as either a monocistronic or polycistronic message. The inability to detect AbpA by immunoblot or ligandbinding assays lends support to such a hypothesis.

The use of the single-specific-primer PCR amplification technique (Shyamala \& Ames, 1989; Novak et al., 1997) proved to be a simple and rapid method for obtaining DNA flanking the Tn916 insertion site. Due to the relatively large size of $T n 916$, analysis of the surrounding DNA often requires a number of manipulations that greatly increase the complexity of the cloning process (Caparon \& Scott, 1987; Caufield et al., 1990). PCR screening of the ligation reaction was very efficient, obviating the need for the more labour-intensive construction and screening of genomic or cDNA libraries. Novak et al. (1997) used this technique to amplify fragments of up to $3.2 \mathrm{~kb}$ and predicted amplicons of up to $35 \mathrm{~kb}$ may be amplified using long PCR methodologies. The application of this technique, as demonstrated by this study, should prove very useful for cloning nucleotide sequences flanking known regions.

\section{Concluding remarks}

In summary, a mutant unable to bind amylase was selected following transposon mutagenesis. This mutant was unable to produce a $20 \mathrm{kDa}$ protein found previously to bind amylase. The gene encoding this protein was subsequently cloned and sequenced; sequence analysis indicated that it encoded a unique secreted, cellassociated protein. These results demonstrate the importance of the $20 \mathrm{kDa}$ protein in the binding of amylase to $S$. gordonii. Future studies will focus on the functional characterization of mutants deficient in amylase-binding in models of oral adhesion and colonization.

\section{ACKNOWLEDGEMENTS}

The authors are grateful to Dr Howard K. Kuramitsu for helpful discussions throughout the course of this work. This study was supported in part by grant DE 09838 (F.A.S.), Dentist Scientist Award DE 00158 (J.D.R.) and Postdoctoral Training Grant DE 07034 (E.M.H.), all from the National 
Institute of Dental Research, and by a Howard Hughes Summer Scholars Fellowship (A.E.B.) from Bates College, Lewiston, ME.

\section{REFERENCES}

Aguirre, A., Levine, M. J., Cohen, R. E. \& Tabak, L. A. (1987). Immunochemical quantitation of $\alpha$-amylase and secretory $\operatorname{IgA}$ in parotid saliva from people of various ages. Arch Oral Biol 32, 297-301.

Altschul, S. F., Gish, W., Miller, W., Myers, E. W. \& Lipman, D. J. (1990). Basic local alignment search tool. J Mol Biol 215, 403-410.

Bairoch, A., Bucher, P. \& Hofmann, K. (1996). The PRosite database, its status in 1995. Nucleic Acids Res 24, 189-196.

Behnke, D. (1981). Plasmid transformation of Streptococcus sanguis (Challis) occurs by circular and linear molecules. Mol Gen Genet 182, 490-497.

Birnboim, H. C. \& Doly, J. (1979). A rapid alkaline extraction procedure for screening recombinant plasmid DNA. Nucleic Acids Res 7, 1513-1523.

Brendel, V., Bucher, P., Nourbakhsh, I., Blaisdell, B. E. \& Karlin, S. (1992). Methods and algorithms for statistical analysis of protein sequences. Proc Natl Acad Sci USA 89, 2002-2006.

Burnette, W. N. (1981). Western blotting : electrophoretic transfer of proteins from sodium dodecyl sulphate-polyacrylamide gels to unmodified nitrocellulose and radiographic detection with antibody and radioiodinated protein A. Anal Biochem 112, 195-203.

Caparon, M. G. \& Scott, J. R. (1987). Identification of a gene that regulates expression of $M$ protein, the major virulence determinant of group A streptococci. Proc Natl Acad Sci USA 84, 8677-8681.

Caufield, P. W., Shah, G. R. \& Hollingshead, S. K. (1990). Use of transposon $\operatorname{Tn} 916$ to inactivate and isolate a mutacin-associated gene from Streptococcus mutans. Infect Immun 58, 4126-4135.

Cimasoni, G., Song, M. \& McBride, B. C. (1987). Effect of crevicular fluid and lysosomal enzymes on the adherence of streptococci and bacteroides to hydroxyapatite. Infect Immun 55, 1484-1489.

Clewell, D. B. (1981). Plasmids, drug resistance, and gene transfer in the genus Streptococcus. Microbiol Rev 45, 409-436.

Coykendall, A. L. \& Gustafson, K. B. (1985). Deoxyribonucleic acid hybridizations among strains of Streptococcus salivarius and Streptococcus bovis. Int J Syst Bacteriol 35, 274-280.

Curby, W. A. (1953). Device for collection of parotid saliva. J Lab Clin Med 41, 493-496.

Douglas, C. W. I. (1983). The binding of human salivary $\alpha$-amylase by oral strains of streptococcal bacteria. Arch Oral Biol 28, 567-573.

Douglas, C.W. I. (1990). Characterization of the $\alpha$-amylase receptor of Streptococcus gordonii NCTC 7868. J Dent Res 69, 1746-1752.

Douglas, C. W. I. (1994). Bacterial-protein interactions in the oral cavity. Adv Dent Res 8, 254-262.

Douglas, C. W. I., Pease, A. A. \& Whiley, R. A. (1990). Amylasebinding as a discriminator among oral streptococci. FEMS Microbiol Lett 66, 193-198.

Douglas, C. W. I., Heath, J. \& Gwynn, J.P. (1992). Enzymic activity of salivary amylase when bound to the surface of oral streptococci. FEMS Microbiol Lett 92, 193-198.

Gawron-Burke, C. \& Clewell, D. B. (1984). Regeneration of insertionally inactivated streptococcal DNA fragments after excision of transposon $\mathrm{Tn} 916$ in Escherichia coli: strategy for targeting and cloning genes from Gram-positive bacteria. $J$ Bacteriol 159, 214-221.

Giulian, G. G., Moss, R. L \& Greaser, M. (1983). Improved methodology for analysis and quantitation of proteins on onedimensional silver-stained slab gels. Anal Biochem 129, 277-287.

Gwynn, J. P. (1995). Characterisation of the interactions between buman salivary $\alpha$-amylase and oral streptococci. $\mathrm{PhD}$ thesis, University of Sheffield.

Gwynn, J. P. \& Douglas, C. W. I. (1994). Comparison of amylasebinding proteins in oral streptococci. FEMS Microbiol Lett 124, 373-380.

Handley, P., Coykendall, A., Beighton, D., Hardie, J. M. \& Whiley, R. A. (1991). Streptococcus crista sp. nov., a viridans streptococcus with tufted fibrils, isolated from the human oral cavity and throat. Int J Syst Bacteriol 41, 543-547.

Harris, G. S., Michalek, S. M. \& Curtis, R. C., III (1992). Cloning of a locus involved in Streptococcus mutans intracellular polysaccharide accumulation and virulence testing of an intracellular polysaccharide-deficient mutant. Infect Immun 60, 3175-3185.

Higgins, M. L. \& Shockman, G. D. (1970). Model for cell wall growth of Streptococcus faecalis. J Bacteriol 101, 643-648.

Jenkinson, H. F. (1994). Cell surface protein receptors in oral streptococci. FEMS Microbiol Lett 121, 133-140.

Kilian, M. \& Nyvad, B. (1990). Ability to bind salivary $\alpha$-amylase discriminates certain viridans streptococcal species. J Clin Microbiol 28, 2576-2577.

Laemmli, U. K. (1970). Cleavage of structural proteins during assembly of the head of bacteriophage T4. Nature 277, 680-685.

LeBlanc, D. J. \& Hassell, F. P. (1976). Transformation of Streptococcus sanguis Challis by plasmid deoxyribonuceic acid from Streptococcus faecalis. J Bacteriol 128, 347-355.

Lottenberg, R., Broder, C. C., Boyle, M. D. P., Kain, S. J., Schroeder, B. L. \& Curtiss, R. (1992). Cloning, sequence analysis and expression in Escherichia coli of a streptococcal plasmin receptor. J Bacteriol 174, 5240-5210.

Macrina, F. L., Evans, R. P., Tobian, J. A., Hartley, D. L., Clewell, D. B. \& Jones, K. R. (1983). Novel shuttle plasmid vehicles for Escherichia-Streptococcus transgeneric cloning. Gene 25, 145159.

Merril, C. R., Goldman, D. \& van Keuren, M. L. (1982). Simplified silver protein detection and image enhancement methods in polyacrylamide gels. Electrophoresis 3, 17-23.

Novak, J., Novak, L., Shah, G. R., Woodruff, W. A. \& Caufield, P. W. (1997). Transposon mutagenesis, cloning of chromosomal DNA from the site of $\operatorname{Tn} 916$ insertion using polymerase chain reaction. Biotechnol Tech 11, 51-54.

Roger, V., Tenovuo, J., Lenander-Lumikari, M., Soderling, E. \& Vilja, P. (1994). Lysozyme and lactoperoxidase inhibit the adherence of Streptococcus mutans NCTC 10449 (serotype c) to saliva-treated hydroxyapatite in vitro. Caries Res 28, 421-428.

Sanger, F., Nicklen, S. \& Coulson, A. R. (1977). DNA sequencing with chain terminating inhibitors. Proc Nat Acad Sci USA 74, 5463-5467.

Scannapieco, F. A. (1994). Saliva-bacterium interactions in oral microbial ecology. Crit Rev Oral Biol Med 5, 203-248.

Scannapieco, F. A., Bergey, E. J., Reddy, M. S. \& Levine, M. J. (1989). Characterization of salivary $\alpha$-amylase binding to Streptococcus sanguis. Infect Immun 57, 2853-2863.

Scannapieco, F. A., Haraszthy, G. G., Cho, M. I. \& Levine, M. J. (1992). Characterization of an amylase-binding component from Streptococcus gordonii G9B. Infect Immun 60, 4726-4733. 
Scannapieco, F. A., Solomon, L. \& Wadenya, R. O. (1994). Emergence in human dental plaque and host distribution of amylase-binding streptococci. J Dent Res 73, 1627-1635.

Scannapieco, F. A., Torres, G. I. \& Levine, M. J. (1995). Salivary amylase promotes adhesion of oral streptococci to hydroxyapatite. J Dent Res 74, 1360-1366.

Schneewind, O., Fowler, A. \& Faull, K. F. (1995). Structure of the cell wall anchor of surface proteins in Staphylococcus aureus. Science 268, 103-106.

Shyamala, V. \& Ames, G. F. (1989). Genome walking by singlespecific-primer polymerase chain reaction: SSP-PCR. Gene 84, $1-8$.

Sutcliffe, I. C. \& Russell, R. R. (1995). Lipoproteins of Grampositive bacteria. J Bacteriol 177, 1123-1128.

Suvorov, A. N., Flores, A. E. \& Ferrieri, P. (1997). Cloning of the glutamine synthetase gene from group B streptococci. Infect Immun 65, 191-196.

Tellefson, L. M. \& Germaine, G. R. (1986). Adherence of Strepto- coccus sanguis to hydroxyapatite coated with lysozyme and lysozyme-supplemented saliva. Infect Immun 51, 750-759.

Terleckyj, B., Willet, N. P. \& Schockman, G. D. (1975). Growth of several cariogenic strains of oral streptococci in a chemically defined medium. Infect Immun 11, 649-655.

Tseng, C. C., Scannapieco, F. A. \& Levine, M. J. (1992). Use of a replica plate assay for the rapid assessment of salivary proteinbacteria interactions. Oral Microbiol Immunol 7, 53-56.

Yamamoto, M., Jones, J. M., Senghas, E., Gawron-Burke, C. \& Clewell, D. B. (1987). Generation of Tn5 insertions in streptococcal conjugative transposon Tn916. Appl Environ Microbiol 53, 1069-1072.

Yanisch-Perron, C., Vieira, J. \& Messing, J. (1985). Improved M13 phage cloning vectors and host strains: nucleotide sequence of the M13mp18 and pUC19 vectors. Gene 33, 103-119.

Received 17 September 1997; revised 12 December 1997; accepted 22 December 1997. 